\title{
Comparative Evaluation of Vein Graft Preparation Media: Electron and Light Microscopic Studies ${ }^{1,2}$
}

\author{
JAMES C. STANLEY, M.D., VIKROM SOTTIURAI, PH.D., M.D., \\ RICHARD E. FRY, B.A., AND WILLIAM J. FRY, M.D. \\ Department of Surgery, Section of General Surgery and the Department of Anatomy, \\ University of Michigan Medical Center, Ann Arbor, Michigan 48104
}

Received November 8, 1974

Arterial reconstructions using autogenous veins are often compromised by late graft stenoses, diffuse constrictions, and occasional aneurysmal dilatations. Comprehensive studies of alterations within vein grafts, following transplantation to the arterial circulation, are few in number. Knowledge is even more meager regarding the immediate effects of differing procurement, preparation and placement techniques upon transplanted veins. The present investigation entails a light and electron microscopic assessment of early cellular and subcellular changes following use of three different vein graft preparation media.

\section{MATERIALS AND METHODS}

Ileofemoral and internal jugular veins were excised from anesthetized adult dogs following intravenous administration of sodium heparin (150 units $/ \mathrm{kg}$ ). Particular care was taken to avoid unnecessary trauma to the vein during dissection and removal. A portion of the vein was immediately fixed for control study. The remaining tissue was divided into thirds, each piece being approximately $2.0 \mathrm{~cm}$ in length. Each segment was rapidly immersed in a different storage solution $(75-100 \mathrm{ml})$ contained in flasks mounted on a platform mechanical agitator.

Preparation media included (I) heparinized whole blood from the host animal at

'Presented before the Eighth Annual Meeting of the Association for Academic Surgery, November 8, 1974, I.os Angeles, CA.

${ }^{2}$ Supported in part by the University of Michigan Peripheral Vascular Research Fund, and the Michigan Heart Association. $20^{\circ} \mathrm{C}$; (II) tissue culture medium at $20^{\circ} \mathrm{C}$; and (III) balanced salt solution at $5^{\circ} \mathrm{C}$. The first medium, venous blood, exhibited osmolalities of approximately $300 \mathrm{mOsm} /$ liter. Initial $p \mathrm{H}$ ranged from 7.3 to 7.6 , and in each instance became more alkalotic during the experiment. The culture medium employed was BME with $10 \%$ calf serum and HEPES buffer. This solution's osmolality was $295 \mathrm{mOsm} /$ liter. Its initial $p \mathrm{H}$ of 7.3 also rose slightly during the storage period. The balanced salt medium employed was lactated Ringers solution with a $p \mathrm{H}$ of 6.5. Electrolyte composition of this solution was $\mathrm{Na}^{+} 130^{+}, \mathrm{K}^{+} 4, \mathrm{Ca}^{++} 3, \mathrm{Cl}^{-} 109$, and $\mathrm{HCO}_{3}-28 \mathrm{meq} /$ liter. This particular medium was frozen and subsequently crushed to form a "slush" prior to use. During tissue storage its osmolality decreased from greater than $550 \mathrm{mOsm} /$ liter initially, to approximately $270 \mathrm{mOsm} /$ liter as melting neared completion. This reflected solute concentration in the liquid portion of the "slush." Veins were subjected to $30-, 60-$, $90-$, and 120-min storage in each medium at which times segments were removed for study. One-hundred-sixty-nine vein specimens, including control tissues, were examined.

Vein segments were fixed immediately in $3 \%$ glutaraldehyde $-2 \%$ paraformaldehyde in cocodylate buffer. Tissue for scanning electron microscopy was critical point dried after ethanol dehydration and amyl acetate immersion. Fixed tissue for transmission electron microscopy was diced into small pieces, approximately $0.5 \mathrm{~mm}^{3}$. These spec- 
imens were postfixed in $2 \% \mathrm{OsO}_{4}$ and stained with $0.5 \%$ uranyl acetate-lead citrate. Following dehydration with ethanol the tissues were embedded in Epon 812. Additional specimens were prepared for light microscopy with hematoxylin and eosin, Verhoeff's and Masson stains. Particular attention was directed to identifying representative areas of each vein that were typical of the entire segment.

\section{RESULTS}

Macroscopic differences among veins incubated in the three preparation solutions became obvious following $30 \mathrm{~min}$ of storage. Most striking were changes occurring in the veins incubated in the salt solution. Increased vessel wall thickness, edematous appearing intimal tissue, and a loss of adventitial compactness, characterized these specimens. Whole blood, and to a lesser degree culture medium, were not associated with such marked morphologic alterations. Gross vessel appearances after periods of storage up to $60 \mathrm{~min}$ in these latter two media were similar to those of control veins.

Scanning electron microscopy documented predictable changes involving intimal structures. Apparent endothelial cell swelling and loss of surface microvilli were common after 90 - to 120 -min storage in all three media. Incubation in whole blood invariably produced alterations of lesser magnitude than were associated with salt solution storage (Fig. 1). Microvilli after 60min whole blood incubation were similar to controls. Even following $120 \mathrm{~min}$, they remained better preserved than after $60-\mathrm{min}$ exposure to salt solution. Intimal ulcers, representing focal cellular disruptions and exposure of subendothelial connective tissue, were frequently observed after 120 -min incubation in salt medium.

Transmission electron microscopy of many vein segments revealed marked derangements of ultrastructural elements and tissue organization. Vessels prepared in whole blood, although far from normal, were least affected. Morphology of veins subjected to brief incubation periods in blood (Fig. 2A) was remarkably similar to the controls. Endothelial cells after preparation in blood for as long as $120 \mathrm{~min}$ were usually intact, maintaining close apposition to relatively normal appearing subendothelial structures (Fig. 2B). Altered smooth muscle cell organelles were demonstrable after long incubations in blood, but were never as pronounced as occurred with other preparation media. Prolonged tissue culture medium storage resulted in frequent detachment of endothelial cells from underlying fragmented connective tissue (Fig. 3). Abnormalities within endothelial basal lamina were more obvious than intracellular alterations, and invariably preceded cell detachment. Degenerative changes of smooth muscle mitochondria and confluences of micropinocytotic vesicles were common findings in these preparations. Disturbance of normal structures occurred with regularity following all balanced salt solution preparations, being most advanced after 120 min (Fig. 4). Tissues treated in this manner were invariably devoid of endothelial cells, manifested marked disruption of subendothelial structures, and exhibited frequent fragmentation of smooth muscle cells. Large intracellular vacuoles, mitochondrial rupture, and loss of recognizable myofilament architecture were commonplace. Intercellular debris and fluids accumulated throughout the vessel wall.

Effects of differing preparation media upon adventitial structures involved significant alterations of vasa vasorum and connective tissue organization. Vasa vasoral endothelial cells exhibited multiple intracellular vesicles and vacuoles following storage in comparison to controls (Fig. 5). These changes were recognized after prolonged storage in all media. Transmission electron microscopy also revealed an increase of adventitial ground substance and cellular debris between widely separated collagen bundles in these specimens.

Light microscopic findings proved to be in agreement with those evolving from electron 

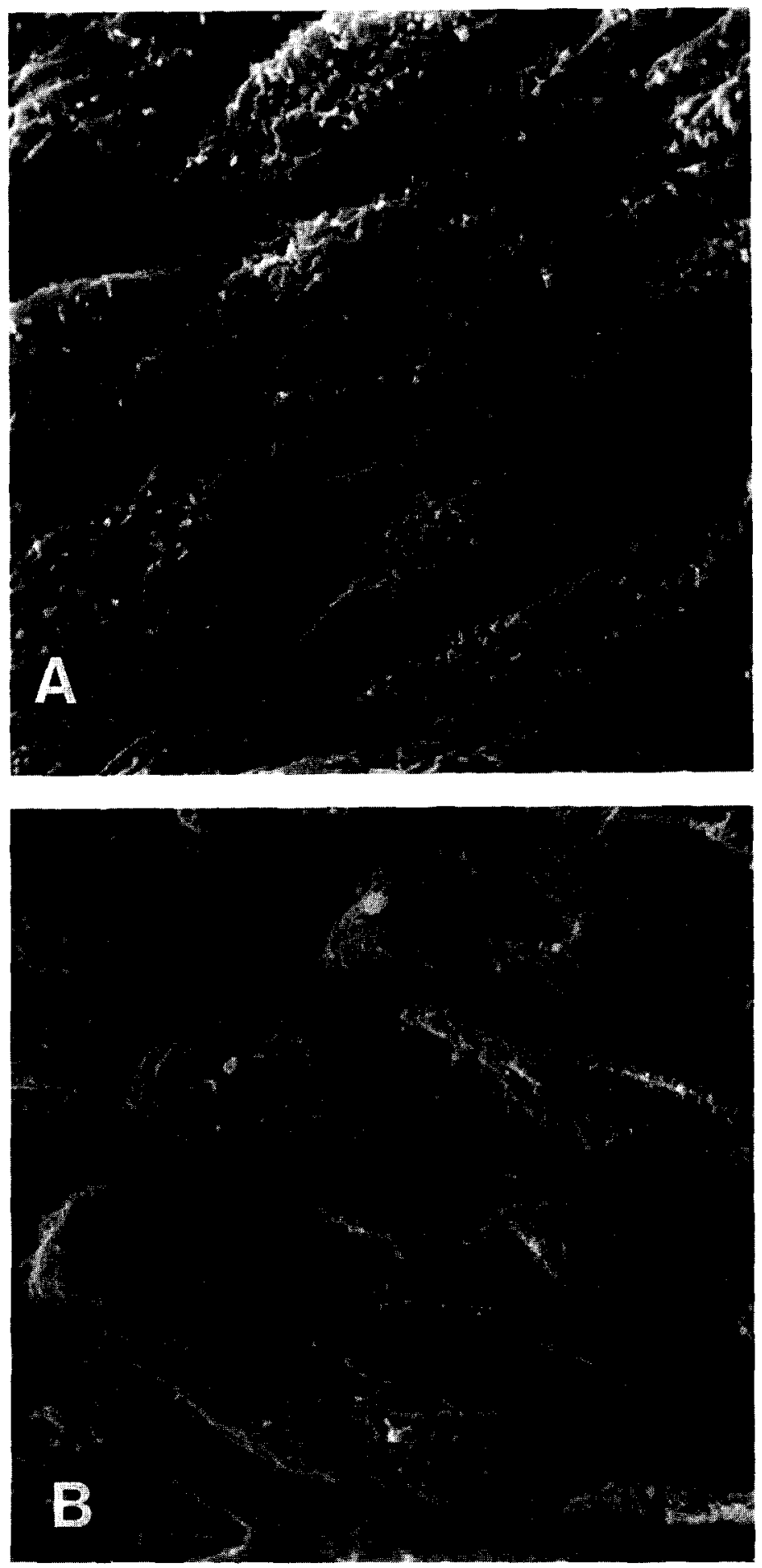

FIG. 1A. Scanning electron micrograph of vein segment incubated $60 \mathrm{~min}$ in whole blood at $20^{\circ} \mathrm{C}(\times 4,000)$. Endothelial cells are intact and microvilli well preserved.

FIG. 1B. Scanning electron micrograph of vein segment incubated $60 \mathrm{~min}$ in balanced salt solution at $5^{\circ} \mathrm{C}$ $(\times 4,000)$, exhibiting apparent endothelial cell swelling and marked diminution of visable microvilli. 


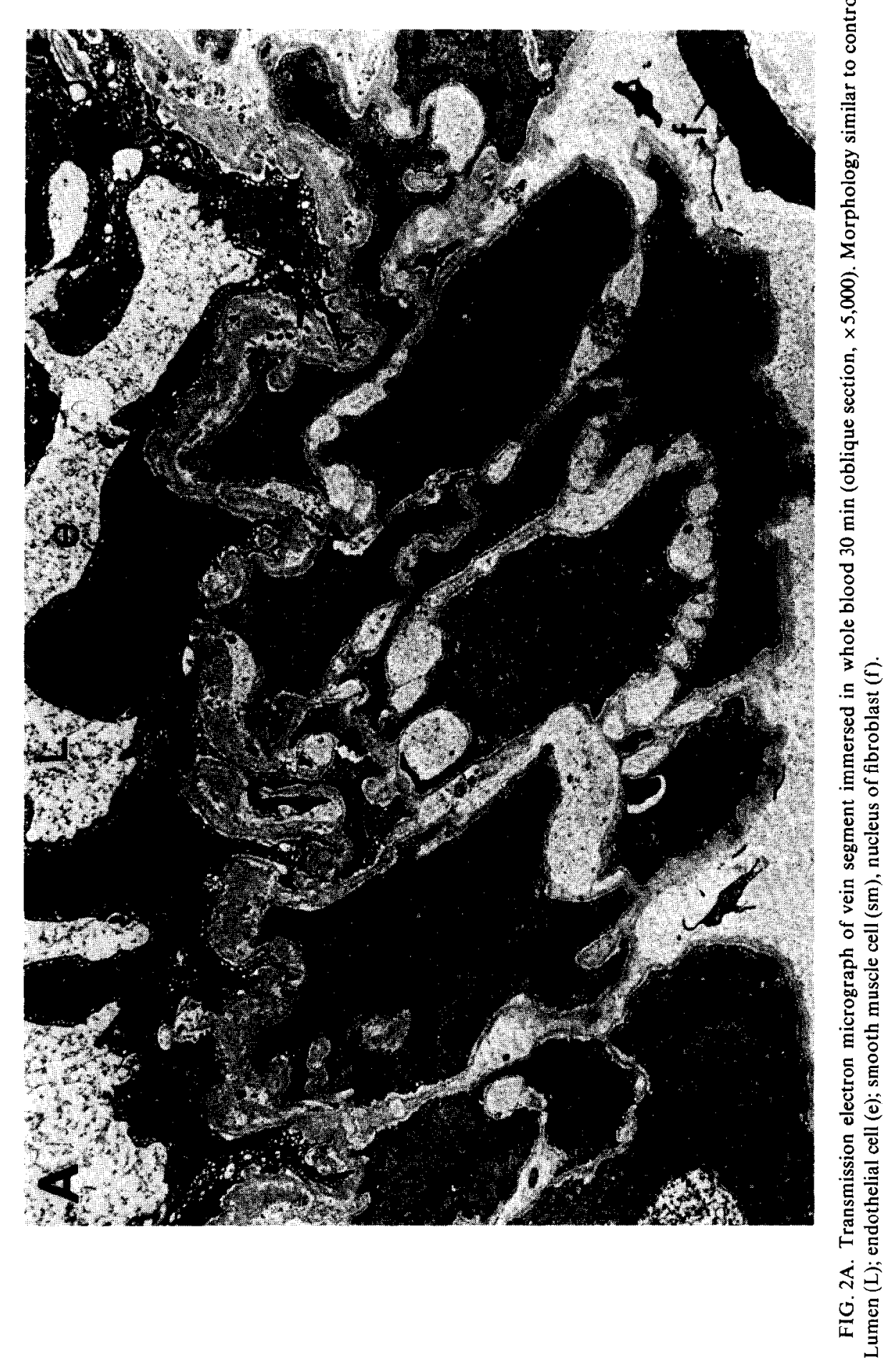




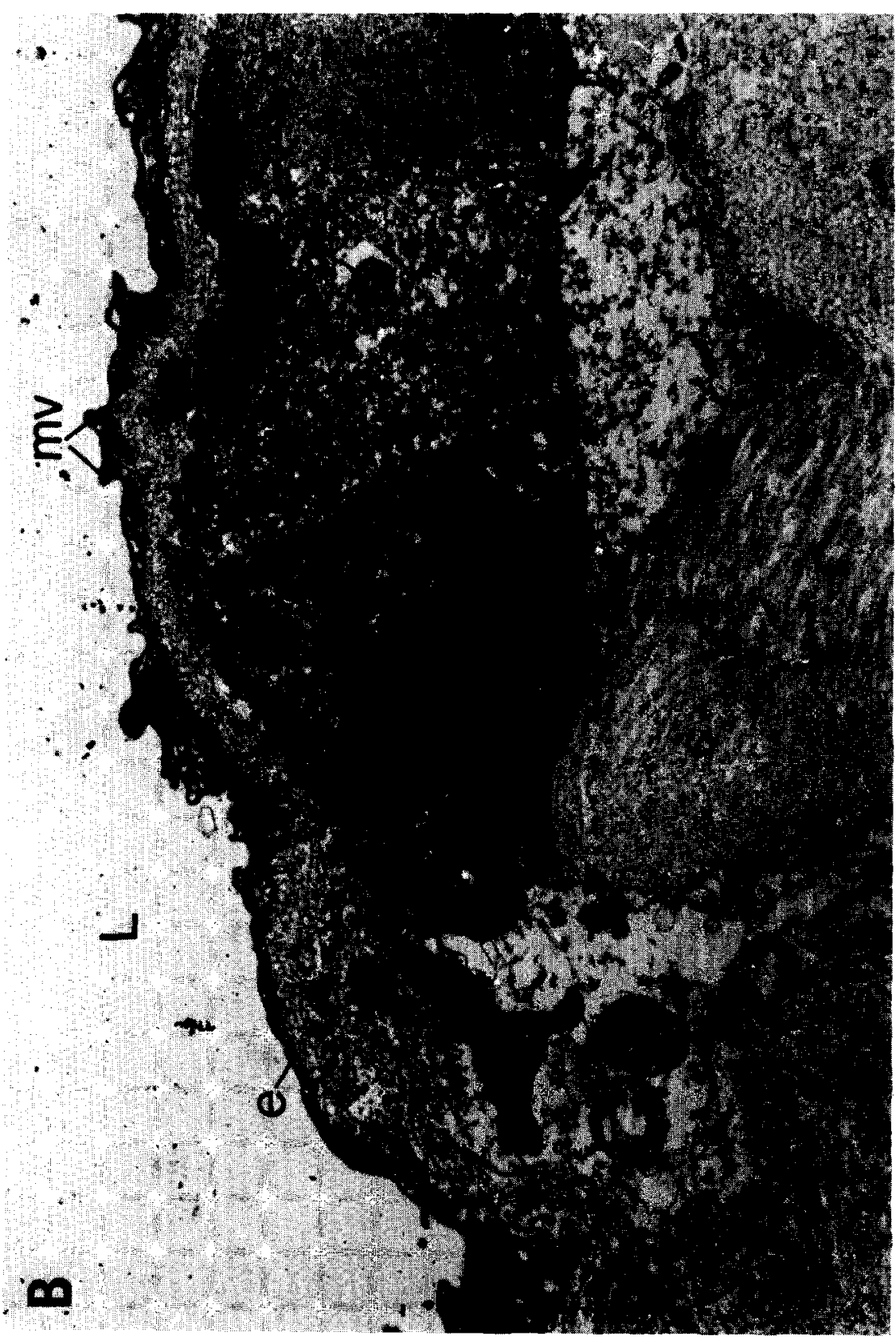

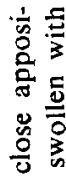

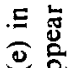

$\overline{\overline{8}}$

E

혼

它

苛

至

䱏点

E

ㅇํㅇ

兽

究

룽

ह

올

뭉요

음

능

䨔路

.

马

产

总

릉

怤

ग

O

京

ํํㅇ

을

光

동

造

जै

등

总虽远

용

든 종 흉

$-3$

呚

ن용

吃总 

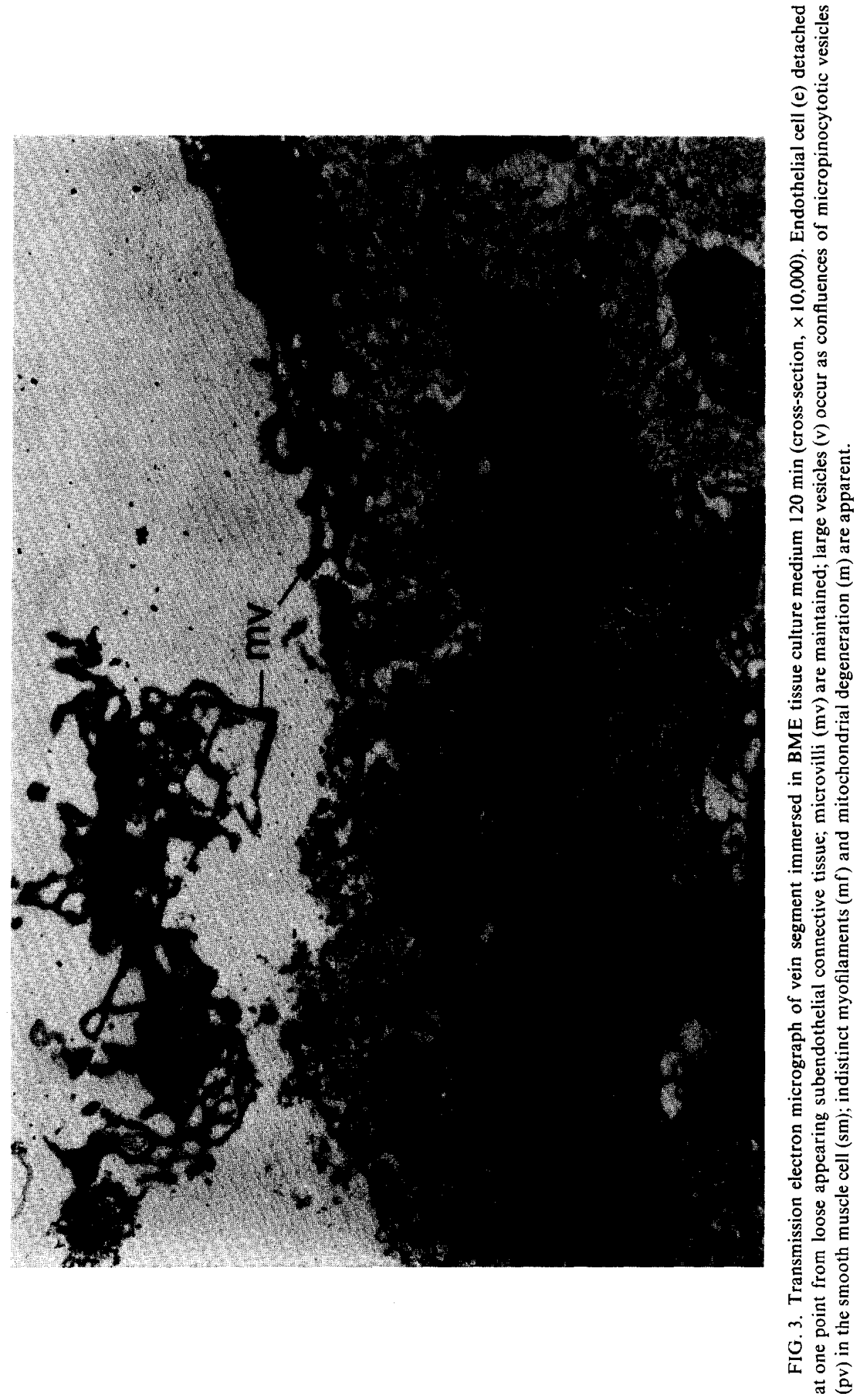

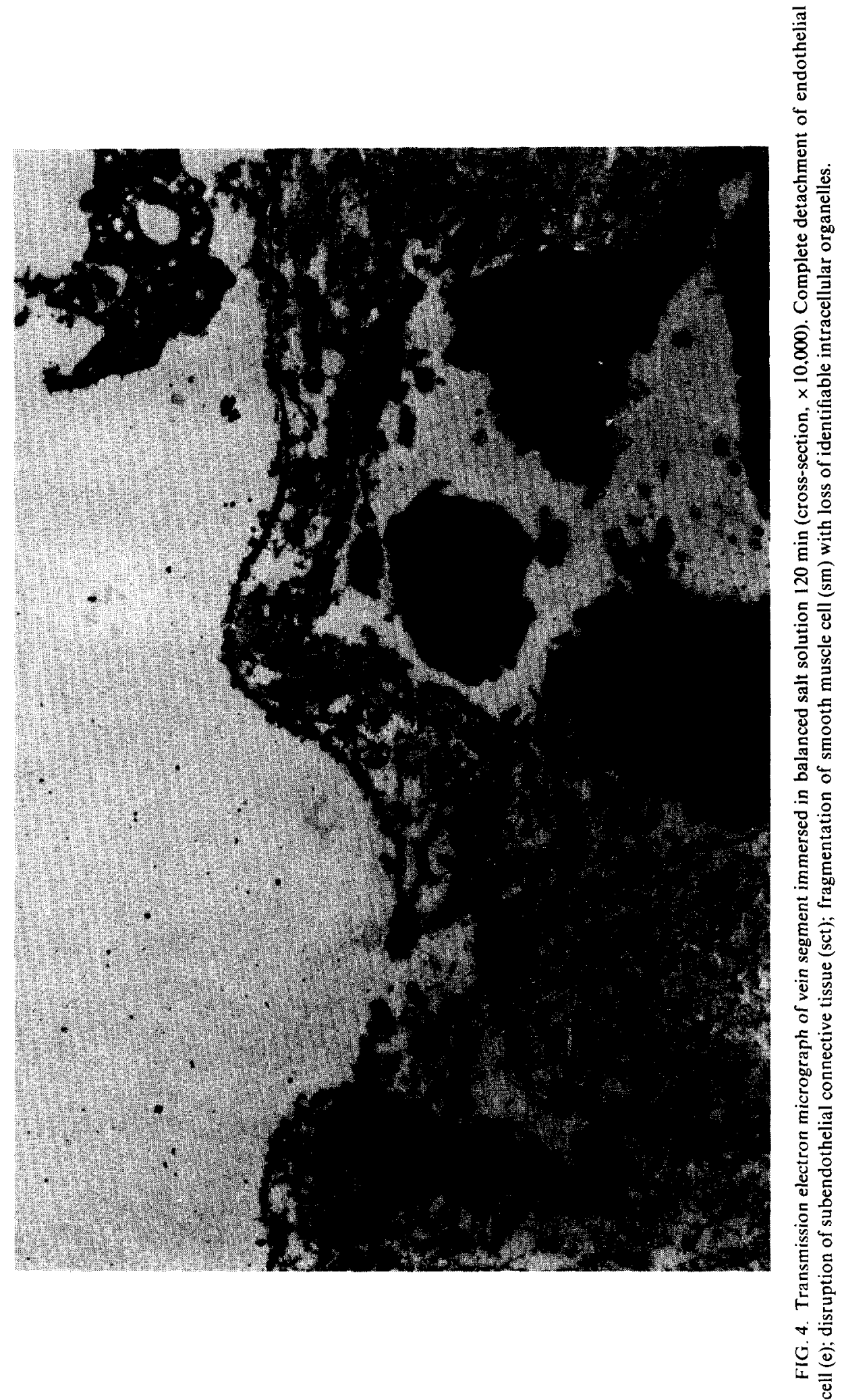

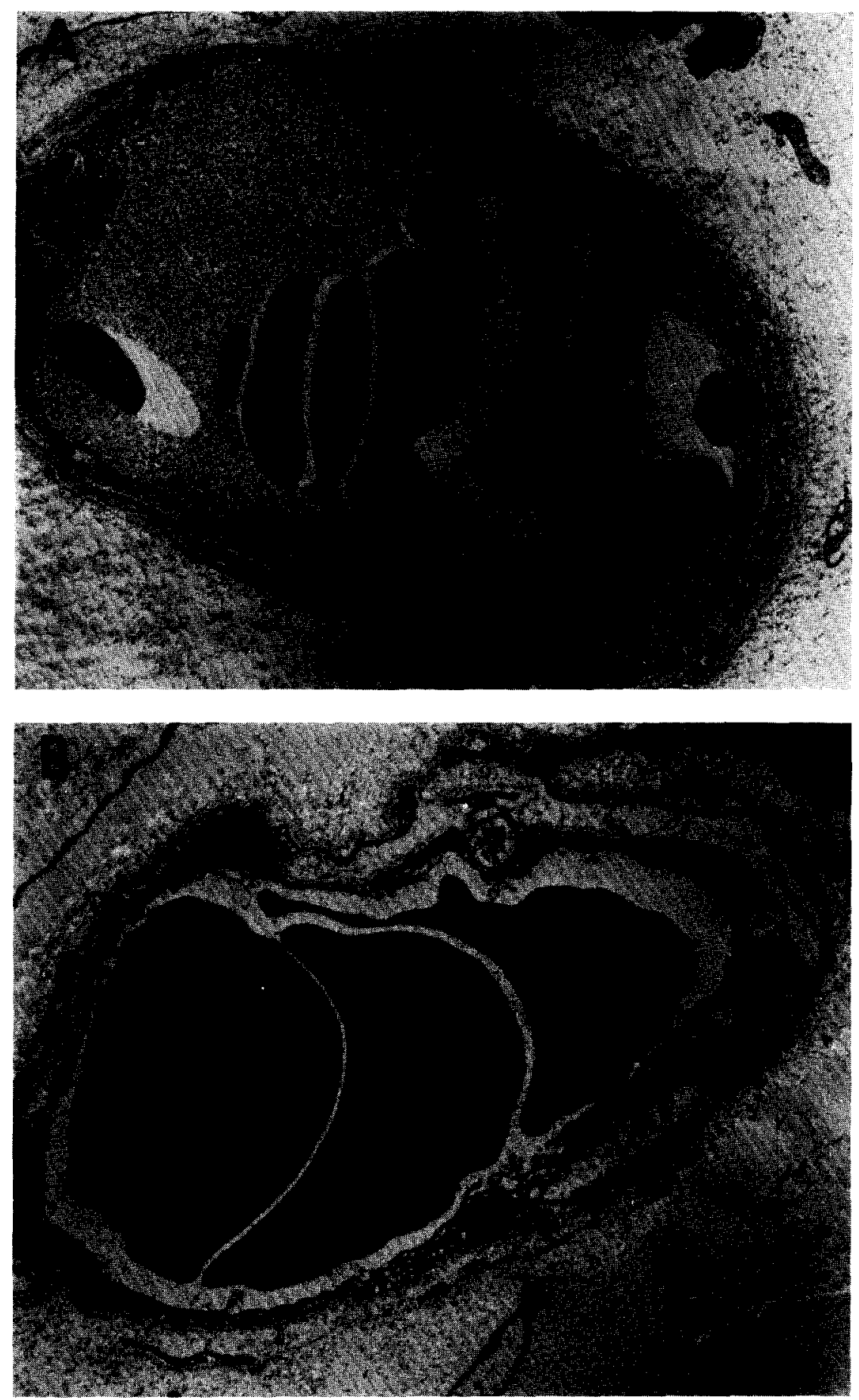

FIG. 5A. Transmission electron micrograph of large, normal vasa vasorum in control specimen (cross-section, $\times 5,000$ ) exhibiting intact endothelial cells.

FIG. 5B. Transmission electron micrograph of vasa vasorum from vein segment incubated in whole blood 120 min (cross-section, $\times 7000$ ) demonstrating extensive vacuolization $(v)$ of endothelial cell (e). 
microscopic studies. Expected intimal disruptions with endothelial cell loss, and increased vessel thickness due to extracellular edema as well as intracellular swelling, could be noted with light studies, but were often poorly defined. Loss of adventitial compactness which often occurred following salt solution storage, was less common in culture medium, and was infrequent after incubation in whole blood (Fig. 6). Quite striking was the repeated paucity of recognizable vasa vasorum within the adventitia of vessels prepared in balanced salt solution for periods greater than $60 \mathrm{~min}$. It was apparent that subtle cellular changes and subcellular events were not discernable using routine studies, and that certain important occurrences such as loss of vasa vasoral elements were not identified by electron microscopic study.

\section{DISCUSSION}

Detailed clinical studies of autogenous saphenous vein aorto-coronary, aortopopliteal, and aorto-renal arterial reconstructions have recently documented an unusually high incidence of graft abnormalities [4-6, 24, 27]. Factors indigenous to the local arterial circulation may be responsible for certain lesions. Diffuse stenoses secondary to intimal fibroplasia in coronary revascularizations, and generalized graft expansion, common in renal artery bypasses, may be a reflection of differing pressure and flow character within these conduits. Numerous experimental and clinical studies have focused attention on the histologic character of autogenous veins exposed to arterial blood flow $[2,12-14,22,24$, $26-29,32,33$ ], including a scattering of reports describing alterations in tissue ultrastructure $[3,7-9,11,18,20,23,25,31$, 34]. Recent investigations have examined the physical properties of veins subjected to differing preparation techniques [1] as well as following long-term implantation within the arterial circulation [30]. Few reports have dealt with morphologic and histologic changes occurring as a consequence of the transplant process $[10,22,31,32]$.

Certain facts emerge from the present study, although interpretation of electron microscopic findings must be tempered by the realization that little has been published concerning the character of normal veins $[11,19,20,25]$. Loss of the intimal lining has been a generally accepted consequence of vein transplantation. Typical endothelial projections [23] became less noticeable in the present study with longer immersion of vein segments. Although the existance of microvilli may reflect structural intactness, electron dense endothelial cell cytoplasm (Fig. 2) raises concern for cell viability [34]. Exposure of subendothelial tissues, enhancing subsequent intraluminal thrombus formation [17], or inflammatory cell response to accumulation of subendothelial debris, may be prerequisite to, and the stimulus for, later fibroplasia. Smooth muscle cells, in contrast to other structures, are relatively resistant to the effects of preparation media (excepting salt solution). This would be expected in light of many studies demonstrating contraction of viable cells in thoroughly dissected vessels mounted for hours in oxygenated physiologic salt solution. This is not to deny that necrosis of certain smooth muscles cells is directly attributable to the transplant process. Fibroblasts, like most smooth muscle cells, appear immune to early morphologic change when immersed in storage media. Adventitial derangements may underlie some late graft abnormalities such as aneurysmal dilatation and medial fibrosis. An understanding of the anatomic distribution of vasa vasorum and the mechanisms of transplanted vein vascularizations [15-17, 21, 26, 33] supports a conviction that the immediate blood supply to medial elements is at best tenuous. Further disruption of remaining vasa vasorum might preclude adequate mural revascularization and result in irreparable medial injury.

Preparation media $p \mathrm{H}$, osmolality, 

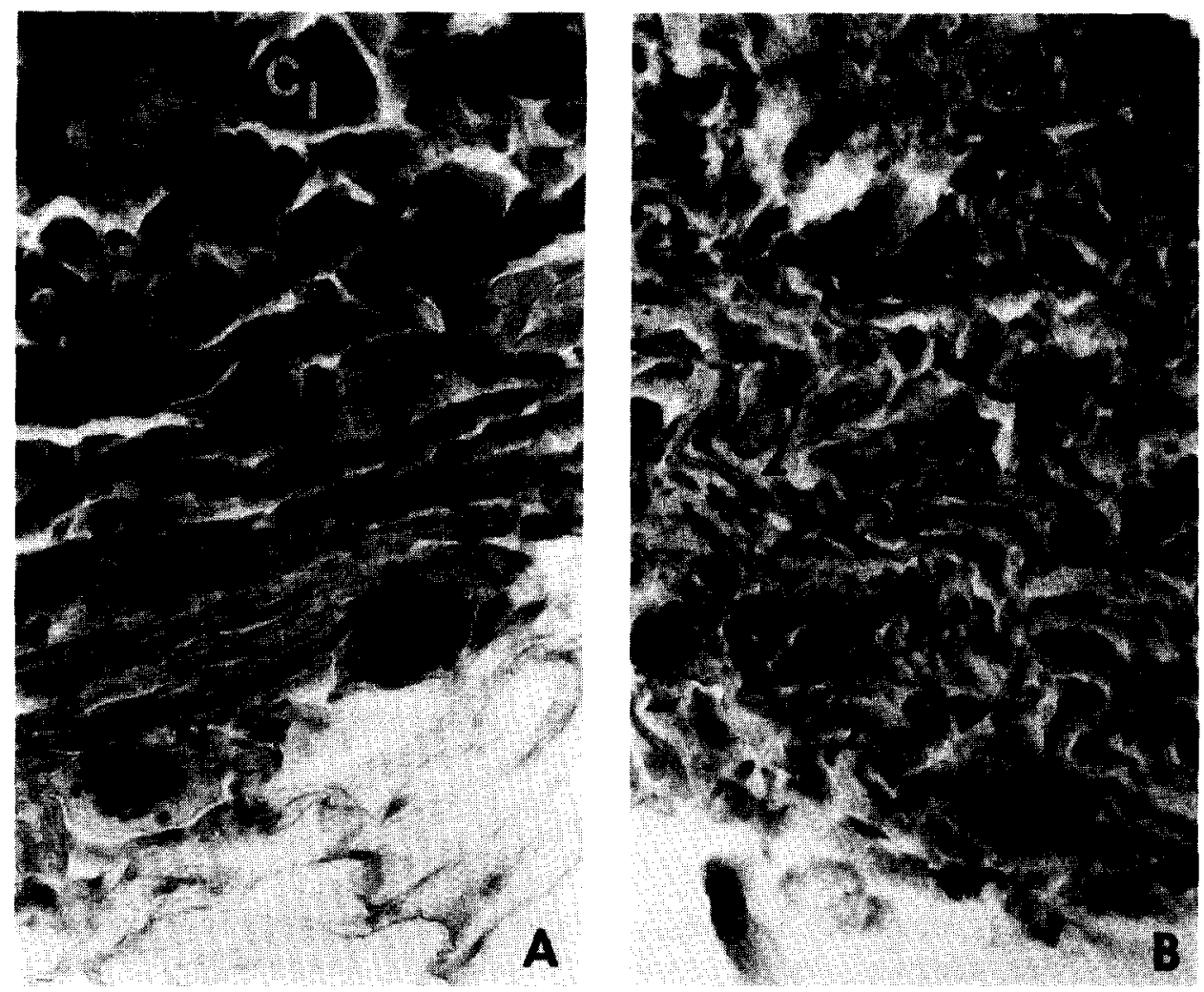

FIG. 6. Light micrograph (Masson stain) of adventitial tissue in control vein $(A) \times 700$, compared to veins subjected to 120 -min storage in whole blood $(B) \times 500$, and 120-min storage in balanced salt solution $(C) \times 500$. Normal compact collagen bundles $\left(c_{1}\right)$ become disorganized and fragmented in tissues exposed to preparation media $\left(c_{2}, c_{3}\right)$; vasa vasorum $\left(v_{1}\right)$ also loses its distinctness $\left(v_{2}\right)$ and undergoes disruption $\left(v_{3}\right)$ during this process.

oxygen tension, and temperature are important variables affecting tissue preservation. Availability of adequate energy substrate is also a necessary factor in maintaining extended cell stability. The sequellae of prolonged vein immersion in an acid "slush," having marked hyperosmolar properties, were well established in this study. Hypothermia with diminution of metabolic activity is desirable in tissue preservation, but the specific method reported herein is not an acceptable means to that end. Different media evaluated in this investigation reflected a choice of solutions currently utilized in many vascular reconstructions employing vein grafts. No attempt to define an optimal preparation medium was intended, although whole blood produced few recognizable morphologic changes in vein segments stored for brief periods of time.

Caution must be exercised in extrapolating early derangements shown in this experiment to the eventual fate of vein grafts. However, the findings should not be ignored. It is unreasonable to expect any reparative process, following disruption of medial smooth muscle cells and intercellular accumulation of debris, not to include significant proliferative fibroplasia. Similarly, disruption of vasa vasorum may eventuate in irreversible mural ischemia. These events, and others incurred during graft procurement, may represent primary factors causing late vein graft failure. Avoidance of cellular and subcellular changes that may be associated with later complications is a logical consideration resulting from the present ex- 


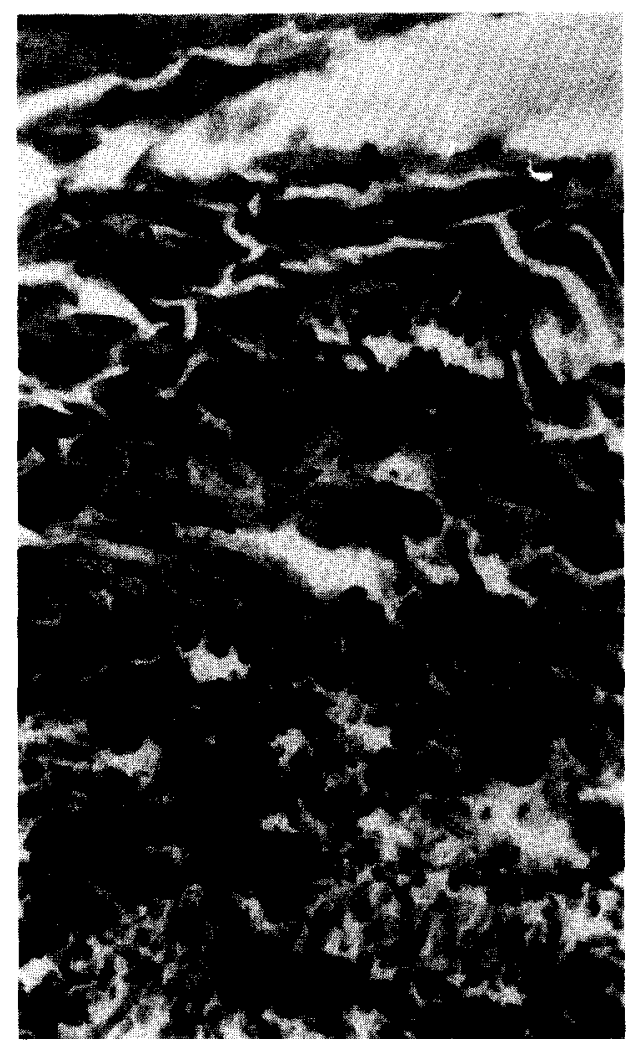

FIG. 6. (continued)

periment. In this regard, whole blood would be preferable to culture medium or balanced salt solution for vein graft preservation under conditions utilized in this investigation.

\section{REFERENCES}

1. Abbott, W. M., Wieland, S., and Austen, W. G. Structural changes during preparation of autogenous venous grafts. Surgery 76:1031-1040, 1974.

2. Brody, W. R., and Angell, W. W. Changes in vein grafts following aorto-coronary bypass induced by pressure and ischemia. $J$. Thorac. Cardiovasc. Surg. 64:847-854, 1972.

3. Brody, W. R., Angell, W. W., and Kosek, J. C. Histologic fate of the venous coronary artery bypass in dogs. Am.J. Pathol. 66:111-129, 1972.

4. Flemma, R. J., Johnson, W. D., Lepley, D., Jr., Tector, A. J., Walker, J., Gale, H., Beddingfield, G., and Manley, J. C. Late results of saphenous vein bypass grafting for myocardial revascularization. Ann. Thorac. Surg. 14: 232 242, 1972.

5. Grondin, C. M., Castonguay, Y. R., Lesperance, J., Bourassa, M. G., Campeau, L., and Grondin, P. Attrition rate of aorto-to-coronary artery saphc- nous vein grafts after one year. Ann. Thorac. Surg. 14:223-231, 1972 .

6. Grondin, C. M., Lesperance, J., Bourassa, M. G., Pasternac, A., Campeau, L., and Grondin, P. Serial angiographic evaluation in 60 consecutive patients with aorto-coronary artery vein grafts 2 weeks, 1 year, and 3 years after operation. J. Thorac. Cardiovasc. Surg. $67: 1-6,1974$.

7. Imparato, A. M., Bracco, A., Kim, G. E., and Zeff, R. Intimal and neointimal fibrous proliferation causing failure of arterial reconstructions. Surgery 72:1007-1017, 1972.

8. Jones, M., Conkle, D. M., Ferrans, V. J., Roberts, W. C., Levine, F. H., Melvin, D. B., and Stinson, E. B. Lesions observed in arterial autogenous vein grafts. Light and electron microscopic evaluation. Circulation (Suppl) 47 and 48:198-210, 1973.

9. Kern, W. H., Dermer, G. B., and Lindesmith, G. C. The intimal proliferation in aortic-coronary saphenous vein grafts: Light and electron microscopic studies. Am. Heart J. 84:771-777, 1972.

10. MacGregor, D. C., Agarwal, V. K., and Silver, M. D. Changes produced in the wall of the saphenous vein of dogs by distending media and pressures. Surg. Forum 23:135-137, 1972.

11. Mahrle, G., and Orfanos, C. E. Stereo-electron microscopy studies on the venous wall. Normal venous endothelium. Arch. Dermatol, Forsch. 242:43-54, 1971.

12. Marti, M. C., Bouchardy, B., and Cox, J. N. Aortocoronary by-pass with autogenous saphenous vein grafts: histopathological aspects. Virchows Arch. Abt. A Path. Anat. 352:255-266, 1971.

13. McCabe, M., Cunningham, G. J., Wyatt, A. P., Rothnie, N. G., and Taylor, G. W. A histological and histochemical examination of autogenous vein grafts. Brit. J.Surg. 54:147-155, 1967.

14. McCabe, M., Wyatt, A. P., and Cunningham, G. J. A study on the ground substance of arteries, veins and grafted veins in dogs. Expt. Molec. Path. 5:531-538, 1966.

15. McCune, W. S., Thistlethwaite, J. R., Keshishian, J. M., and Blades, B. The nutrition of blood vessel grafts. Surg. Gynec. \& Obstet. 94:311-316, 1952.

16. Nylander, G., and Olerud, S. The distribution of the vasa vasorum in the abdominal aorta and the vena cava inferior in dogs. Angiology $11: 522-529,1960$.

17. O'Neil, J. F. The effects on venous endothelium of alterations in blood flow through the vessels in vein walls, and the possible relation to thrombosis. $A n n$. Surg. 126:270-288, 1947.

18. Reichle, F. A., Stewart, G. J., and Essa, N. A transmission and scanning electron microscopic study of luminal surfaces in dacron and autogenous vein bypasses in man and dog. Surgery 74:945-960, 1973.

19. Rhodin, J. A. G. Histology. A Text and Atlas. London/Toronto, 1974, New York, Oxford University Press, pp. 362-366. 
20. Rhodin, J. A. G. Ultrastructure of mammalian venous capillaries, venules and small collecting veins. J. Ultrastruct. Res. $25: 452-500,1968$.

21. Short, R. H. D. The vasa vasorum of the femoral vein. J. Path. Bact. 50:419-430, 1940.

22. Silver, M. D., MacGregor, D. C., Agarwal, V. K., and Lixfield, W. Aortocoronary bypass graft: Early histologic changes in dogs. Canad. J. Surg. 16:246 $251,1973$.

23. Smith, U., Ryan, J. W., Michie, D. D., and Smith, D. S. Endothelial projections as revealed by scanning electron microscopy. Science 173:925-927, $1971^{\circ}$.

24. Stanley, J. C., Ernst, C. B., and Fry, W. J. Fate of 100 aortorenal vein grafts: Characteristics of late graft expansion, aneurysmal dilatation and stenosis. Surgery 74:931-944, 1973.

25. Stewart, G. J., Ritchie, W. G. M., and Lynch, P. R. A scanning and transmission electron microscopic study of canine jugular veins. In Scanning Electron Microscopy/1973 (Part III). Proceedings of the Workshop on Scanning Electron Microscopy in Pathology. Chicago: IIT Research Institute, 1973. Pp. 473-480, 789.

26. Sugiura, A. An experimental study on the vasa vasorum of the venous graft used in arterial replacement. Jap. Circ. J. 32:727-744, 1968.

27. Szilagyi, D. E., Elliot, J. P., Hageman, J. H., Smith, R. F., and Dall'Olmo, C. A. Biologic fate of autogenous vein implants as arterial substitutes: Clinical, angiographic and histopathologic observa- tions in femoro-popliteal operations for atherosclerosis. Ann. Surg. 178:232-246, 1973.

28. Urschel, H. C., Razzuk, M. A., Wood, R. E., and Paulson, D. L. Factors influencing patency of aortocoronary artery saphenous vein grafts. Surgery 72:1048-1063, 1972.

29. Vlodaver, Z., and Edwards, J. E. Pathologic changes in aortic-coronary arterial saphenous vein grafts. Circulation 44:719-728, 1971.

30. Waddell, W. G., Vogelfanger, I. J., Bosc, M., Malik, K. U., MacConaill, M., and Ling, G. Changes in contractility, compliance and elasticity in experimental arterial veinautografts. Canad. $J$. Surg. 16:252-260, 1973.

31. Watson, J. H. L., Swedo, J. L., and Vrandecic, M. Control of autogenous vein grafts prior to reimplantation by electron microscopy. In Thirtieth $A n$ nual Proceedings Electron Microscopy Society of America (Arceneaux, C. J., Ed.). Baton Rouge, LA: Claitor's 1972. Pp. 106-107.

32. Wyatt, A. P., and Taylor, G. W. Vein grafts: Changes in the endothelium of autogenous free vein grafts used as arterial replacements. Brit. J. Surg. 53:943-947, 1966.

33. Wyatt, A. P., Rothnie, N. G., and Taylor, G. W. The vascularization of vein-grafts. Brit. J. Surg. 51:378-381, 1964.

34. Zwillenberg, H. H. L., Zwillenberg, L. O., and Laszt, L. Ultrastructural changes in organ cultures of bovine veins. Angiologica 9:292-300, 1972. 